\title{
Implikatur Percakapan pada Mombesara Perkawinan Suku Tolaki
}

\author{
Disa Arliwan 1 \\ Alan $^{2}$
}

\author{
${ }^{12}$ Fakultas Keguruan dan Ilmu Pendidikan, Universitas Lakidende
}

1disa.arliwan5@gmail.com

2alan86libra@gmail.com

\begin{abstract}
Abstrak
Penelitian ini bertujuan mendeskripsikan implikatur percakapan mombesara pada perkawina suku tolaki. Jenis penelitian ini adalah penelitian kualitatif yang bersifat deskriftif. Teknik pengumpulan data dalam penelitian ini ialah 1). teknik rekam yaitu proses pengambilan data dari informan dengan menggunakan alat rekam, 2). Teknik catat yaitu digunakan untuk mencatat hal-hal yang dianggap penting di luar data rekaman untuk menjaring informasi tambahan, 3). Teknik transkripsi yaitu mengalihkan data dari bahasa lisan menjadi bahasa tulis dan 4). Teknik terjemahan; yaitu mengalihbahasakan data mombesara yang berbahasa Tolaki ke dalam bahasa Indonesia. Hasil penelitian dalam Implikatur Percakapan pada Mombesara Perkawinan Suku Tolaki ialah bahwa percakapan Mombesara adat perkawinan etnis Tolaki didukung oleh unsur-unsur implikatur. Dalam tahap tersebut terdapat percakapan yang maknanya tidak disampaikan secara langsung yaitu pada tahap Morake-rakepi (meninjau calon istri), tahap Monduutudu (pelamaran penjajakan), tahap Mondonggo Niwule/Moawo Niwule (peminangan resmi), dan tahap Mowindahako (upacara adat perkawinan/penyelesaian).
\end{abstract}

Kata kunci: Pragmatik, implikatur, mombesara, tuturan

\section{Pendahuluan}

Bahasa sebagai sarana komunikasi antar penuturnya mempunyai peranan penting dalam kehidupan sehari-hari, karena manusia dalam beraktivitas tidak terlepas dari manusia lain, bahkan dengan lingkungan sekalipun. Dalam upaya memenuhi kebutuhan kita sehari-hari bahasa sangatlah perlu di gunakan baik lisan maupun tulisan. Bahasa adalah alat komunikasi antar sesama, dalam hubungan antar sesama penutur bahasa yang sama antar penutur bahasa yang lainnya. Dalam mempergunakan bahasa baik sebagai alat komunikasi sesama penutur membutuhkan pengetahuan.

Pragmatik merupakan salah satu cabang ilmu linguistik yang mengkaji makna sebuah tuturan dari penutur dan mitra tutur yang sangat ditentukan oleh hubungan antara bahasa dan konteksnya. Pragmatik memiliki peran yang sangat penting dalam memahami sebuah ujaran yang disampaikan karena, makna sebuah tuturan itu sesuai dengan konteks yang melatarbelakanginya. Sebuah tuturan akan sulit dipahami maksud atau tujuannya tanpa adanya konteks. Jadi konteks adalah sesuatu yang menjadi sarana penjelas akan suatu maksud. Salah satu yang dikaji dalam ilmu pragmatik adalah implikatur percakapan.

Pragmatik adalah cabang ilmu bahasa yang mempelajari struktur makna bahasa secara eksternal, yaitu bagaimana satuan kebahasaan itu digunakan di dalam komunikasi. Hal ini senada dengan Rahardi (2005:49) pragmatik adalah ilmu yang 
mempelajari kondisi penggunaan bahasa manusia yang pada dasarnya sangat ditentukan oleh konteks yang mewadahi dan melatarbelakangi bahasa itu. Senada dengan pendapat sebelumnya Wijana (2010:3-4) yang mengemukakan bahwa pragmatik adalah cabang ilmu bahasa yang mempelajari struktur bahasa secara eksternal, yaitu bagaimana satuan kebahasaan itu digunakan di dalam komunikasi.

Mombesara pada prinsipnya merupakan sarana komunikasi dalam upacara adat masyarakat Tolaki. Pada tuturan mombesara terdapat dua penutur, yakni Tolea penutur adat mombesara pihak laki-laki, dan Pabitara penutur mombesara dari pihak perempuan. Penutur Tolea merupakan penutur inti atau kunci dalam setiap pelaksanaan adat mombesara yang merupakan juru bicara dari pihak laki-laki, sedangkan penutur Pabitara merupakan penutur pelengkap yang merupakan pemberi jawaban atas pertanyaan adat berupa tuturan mombesara dari pihak perempuan.

Bahasa dalam percakapan Mombesara bisa beragam dan bisa menimbulkan sebuah implikatur percakapan yang menarik. Terkadang untuk mengerti maksud dari bahasa mombesara seseorang harus mengetahui konteks situasi. Apabila seseorang tidak mengetahui konteks situasi, seseorang itu bisa tergelincir dalam suatu maksud yang tidak sama dengan apa yang dikehendaki oleh penutur tersebut. Seseorang perlu mempunyai suatu kerjasama supaya mengerti maksud tuturan yang dilontarkan. Kerjasama yang dimaksudkan adalah pengetahuan latar belakang dan konteks situasi. Konteks situasi itu bisa berupa tempat, waktu, kebudayaan, dan sebagainya.

Beranjak dari latar belakang yang telah diuraikan di atas, peneliti tertarik untuk meneliti implikatur percakapan yang terdapat pada tuturan mombesara pada acara perkawinan suku tolaki. Penelitian terhadap mombesara pada acara perkawinan suku tolaki layak untuk dilakukan dengan alasan bahwa bahasa dalam mombesara pada acara perkawinan suku tolaki mengandung fenomena kebahasaan yang menarik untuk diteliti.

\section{Metode}

\section{Lokasi, Obyek dan Unit Analisis Penelitian}

Lokasi penelitian ini akan dilaksanakan di Desa Sanggona Kecamatan Konawe Kabupaten Konawe. Obyek penelitian ini adalah Tolea, Pabitara, Puutobu dan Tokoh Masyarakat yang dipandang cukup dan menguasai serta memahami untuk memberikan informasi yang diperlukan sesuai dengan penelitian yang berhubungan dengan upacara adat mombesara. Teknik Pengumpulan Data

1) Teknik rekam; yaitu proses pengambilan data dari informan dengan menggunakan alat rekam.

2) Teknik catat; yaitu digunakan untuk mencatat hal-hal yang dianggap penting di luar data rekaman untuk menjaring informasi tambahan.

3) Teknik transkripsi; yaitu mengalihkan data dari bahasa lisan menjadi bahasa tulis.

4) Teknik terjemahan; yaitu mengalihbahasakan data mombesara yang berbahasa Tolaki ke dalam bahasa Indonesia.

\section{Analisis Data}

Teknik analisis data yang digunakan dalam penelitian ini adalah analisis model interaktif (Interactive Model of Analysis). Menurut Miles dan Huberman (2014: 10) dalam model tersebut ada tiga komponen analisis, yaitu reduksi data, sajian data dan penarikan kesimpulan yang dilakukan dengan bentuk interaktif dan proses pengumpulan data (data collecting) sebagai suatu siklus. Ketiga kegiatan dalam analisis model interaktif dapat dijelaskan sebagai berikut: 
a. Reduksi data (data reduction), merupakan suatu bentuk analisis yang menajamkan, menggolongkan, mengarahkan, membuang yang tidak perlu dan mengorganisasikan data.

b. Penyajian data (data display), merupakan sekumpulan informasi tersusun yang memberikan kemungkinan adanya penarikan kesimpulan dan pengambilan tindakan. Dengan penyajian data, peneliti akan dapat memahami apa yang sedang terjadi dan apa yang harus dilakukan berdasarkan pemahaman tentang penyajian data.

c. Penarikan kesimpulan (conclusion drawing), yaitu kesimpulan yang diambil akan ditangani secara longgar dan tetap terbuka sehingga kesimpulan yang semula belum jelas, kemudian akan meningkat menjadi lebih rinci. Kesimpulan tersebut juga diverifikasi selama penelitian berlangsung. Penyajian data selanjutnya disusun dalam bentuk uraian atau laporan, sesuai dengan hasil penelitian yang diperoleh.

\section{Hasil}

Implikatur merupakan salah satu kajian dalam pragmatik. Secara sederhana implikatur adalah makna tidak langsung atau makna tersirat yang ditimbulkan oleh yang tersurat. Implikatur dimaksudkan sebagai suatu ujaran yang menyiratkan suatu yang berbeda dengan yang sebenarnya diucapkan. Menggunakan implikatur dalam percakapan berarti menyatakan sesuatu secara tidak langsung.

Tuturan Mombesara adat perkawinan suku Tolaki disampaikan secara tidak langsung melalui simbol makhluk hidup dan benda-benda lainnya. Pemilihan simbolsimbol dalam penyampaian pesan bukan tanpa fungsi. Pemilihan simbol-simbol ini berfungsi untuk mengungkapkan sesuatu secara kias tetapi sarat makna. Untuk menentukan makna seseorang harus memiliki kemampuan menginterpretasi simbolsimbol tersebut dengan menentukan referensi yang dirujuknya, serta harus memahami makna kata demi kata serta makna denotatif maupun makna konotatifnya.

Banyak terdapat ungkapan, diksi dan gaya bahasa yang digunakan dalam tuturan mombesara baik oleh Tolea sebagai juru bicara pihak laki-laki, muapun oleh Pabitara sebagai juru bicara pihak perempuan. Penggunaan gaya bahasa tentunya bertujuan untuk memperindah dan memperhalus bahasa serta untuk memperkuat nuansa makna dalam menyampaikan maksud pembicaraan. Hal ini dapat dilihat dalam analisis berikut.

\section{Implikatur pada Tahap Pertama : Morake-rakepi/Mohawu Wuanda'inahu (Pra Melamar)}

Tahapan pertama dalam prosesi Mombesara yaitu morake-rakepi/mohawu wuanda'inahu (pra melamar). Bagi seorang laki-laki yang telah menetapkan pasangan hidupnya, menyampaikan keinginannya kepada orangtuanya untuk ditindaklanjuti secara adat melalui tahap-tahap pembicaraan berdasarkan ketentuan hukum adat yang berlaku. Pihak orangtua memusyawarahkan hal itu jika dipandang perlu bersama beberapa orang saudara terdekat mereka.

Setelah dikaji lebih mendalam yang didasarkan pada berbagai aspek pertimbangan yang dipandang perlu, maka apabila kesimpulannya ada pemberian dukungan yang positif, maka dipersiapknlah satu tim khusus yang akan dikirim kepada keluarga perempuan yang terdiri dari laki-laki yang sudah berkeluarga dari jajaran saudara terdekat yang tentunya memahami adat perkawinan masyarakat Tolaki dan dipandang mampu berdiplomasi.

Setelah ada kepastian waktu untuk penerimaan mereka, maka rombongan segera mempersiapkan diri untuk melaksanakan lawatannya. Tim ini belum membawa perangkat adat dan belum didampingi Tolea (Juru bicara pihak laki-laki) karena sifatnya 
masih dalam koridor nonformal. Sebagai prolog pimpinan rombongan harus pandai mengarahkan pembicaraan seputar maksud hati yang hendak disampaikan. Pimpinan rombongan mulai mengutarakan maksud dari kunjungan mereka.

Dalam menyampaikan maksud, utusan keluarga laki-laki tentunya harus menyampaikannya dengan tutur kata yang lembut. Penggunaan gaya bahasa sangat penting untuk dapat menyampaikan maksud dengan baik. Mengawali proses mombesara, utusan keluarga laki-laki memulai dengan kata-kata penghormatan kepada kedua orang tua perempuan. Kemudian menyampaikan tujuan kedatangan dengan kalimat:

("Laa'i wuhowuho i wowa engero momberongo i aambenaoro. Nggoleu morekapi mohawu wuandainahu $i$ wuta mohaimiu, i tonga inimomiu. Keno ehepokaa ano renei usa nggoruruwai ano oru bosa-timba ano tewosi aroikaa oru leu sumairai.Teresaano tuluramami-rambahino eroimami nikaa saramami asomata").

Terjemahan :

Ada sesuatu wewangian yang tercium dan tependam dalam hati. Untuk datang berbasa-basi bermaksud menabur benih sayuran, ditanah yang hangus, di tengah-tengah ladang kalian. Semoga hujun turun mengguyuri benih tersebut sehingga cepat tumbuh, cepat berkembang dan mereka akan segera datang untuk membersihkan ladang tersebut. Sebagai alas kata basa-basi kami bersama ini kami persembahkan adat kami satu mata). Penggunaan gaya bahasa sudah mulai nampak pada ungkapan ini.

\section{Implikatur pada Tahap Kedua : Monduutudu (Melamar)}

Pada tahap ini, orang tua laki-laki mengutus beberapa orang ke rumah keluarga perempuan yang dipimpin oleh Tolea (juru bicara pihak laki-laki) untuk menyampaikan maksud bahwa mereka ingin melamar anak perempuan keluarga tersebut. Sebelum utusan keluarga laki-laki melakukan kunjungan, salah seorang dari pihak keluarga diutus untuk menemui orang tua perempuan agar memperoleh kepastian adanya waktu yang luang untuk menerima kunjungan mereka nanti.

Dalam menyampaikan maksud, utusan keluarga laki-laki yang dipimpin oleh Tolea tentunya harus menyampaikannya dengan tutur kata yang lembut. Penggunaan gaya bahasa sangat penting untuk dapat menyampaikan maksud dengan baik. Mengawali proses mombesara, Tolea memulai dengan kata-kata penghormatan dan penghargaan kepada kedua orang tua perempuan, Pabitara (juru bicara pihak perempuan) dan seluruh keluarga yang hadir pada saat itu, kemudian mulai menyampaikan maksud kedatangan mereka kepada pihak perempuan. Kata-kata penghormatan ini tentu sangat penting mengingat prosesi mombesara ini adalah sesuatu yang bersifat formal dimana di dalam proses mombesara dihadiri oleh tokoh-tokoh adat dan pemerintah setempat.

Dalam penyampaian maksud pembicaraan, Juru bicara pihak laki-laki kerap menyampaikannya dengan menggunakan gaya bahasa misalnya pada ungkapan :

"menggau'iroto Amano i Arman ronga Inano i Arman nolaa wuho-wuho i wowa engero momberongo i'ambenaoro, rolaa mo'une-une ronga mombeohawa lako ihanumiu nggomodulu owine mosimbi wuta mohai" (telah sekian lama mereka Bapaknya Arman serta Ibunya Arman memendam suatu rasa dan memiliki suatu keinginan terhadap keluarga tuan rumah untuk menyatukan padi dan memperluas ladang).

Penyampaian dengan gaya seperti ini tentu memiliki maksud. Juru bicara pihak laki-laki tidak igin menyampaikan keinginan mereka secara langsung, melainkan melalui gaya bahasa yang mengandung banyak kiasan dengan tujuan menghormati keluarga pihak perempuan. Ungkapan "nggomodulu owine mosimbi wuta mohai" (menyatukan padi dan memperluas ladang) berimplikasi mempersatukan dua rumpun keluarga sehingga menjadi sebuah keluarga yang besar. Pemilihan kata "owine" (padi) dan "wuta mohai" (ladang) tentunya disesuaikan dengan konteks masyarakat Tolaki yang sebagian 
besar masyarakatnya bekerja sebagai petani. Sehingga pihak keluarga perempuan dapat dengan mudah memahami maksud yang disampaikan oleh juru bicara pihak laki-laki.

\section{Implikatur pada Tahap Ketiga : Mowawo Niwule (Meminang)}

Tahap kedua dalam proses upacara adat perkawinan masyarakat Tolaki adalah mowawo niwule (meminang). Tahapan ini merupakan tahap peminangan secara resmi. Hal pokok yang dibicarakan dalam tahapan ini adalah penetapan waktu, dan tempat pelaksanaan pesta perkawinan serta maskawin atau mahar yang akan dipenuhi oleh pihak laki-laki.

Dalam prosesi mombesara yang terjadi pada tahap ini, baik Tolea sebagai juru bicara pihak laki-laki, maupun Pabitara sebagai juru bicara pihak perempuan sama-sama memainkan perannya dalam berkomunikasi. Keduanya membawa amanah dari pihak keluarga. Mereka diberi kepercayaan untuk mewakili pihak keluarga dalam menetapkan segala sesuatu yang berkenaan dengan urusan adat baik berkenaan dengan waktu dan tempat pelaksanaan pesta pernikahan, maupun jumlah mahar yang harus dipenuhi.

Sebagai kata-kata pembuka, mombesara diawali dengan ucapan penghormatan kepada pihak keluarga perempuan. Hal ini tentu didasari oleh karakter semua suku-suku bangsa di Indoenesia yang sangat menjujung tinggi nilai-nilai kekeluargaan. Dalam tahapan ini, kemampuan berkomunikasi juru bicara pihak laki-laki sangat dibutuhkan dalam rangka mengemban misi yang dibebankan pundaknya dalam menegosiasikan waktu pelaksanaan serta mahar yang akan ditanggung oleh pihak laki-laki. Kepercayaan penuh yang diberikan pihak keluarga laki-laki tentu menjadi tanggung jawab yang harus ia dilaksanakan dengan baik.

Pada pelaksanaan mombesara dalam tahapan mowawoniwule (meminang) ini, kerap kali terjadi permainan kata antara juru bicara pihak laki-laki dan juru bicara pihak perempuan dalam memperjuangkan kepentingan masing-masing yang tentunya menggunakan tutur kata yang halus dan santun serta selalu menjujung nilai-nilai kekeluargaan.

Misalnya pada ungkapan :

"Ki ari leu ihawi, inipua umete'ete'ikomiu la'usamiu,dumendedende'ikomiu tambomiu, aki'amba membuleako notule'i te'eni unemiu, mosaru penaomiu ki'oki no'une sawatuumami. Kondeenokaa kilaa lako rumuku'i osala, rumuru'i batatana, anomepeokomami oleo, tumudukomami o'usa aki telalo melolu, mesoo'ako i lolu laika miu"

\section{Terjemahan :}

(Kedatangan kami beberapa waktu yang lalu untuk mencoba menaiki tangga kalian, mencoba membuka pintu kalian, dan setelah kami kembali mungkin ada dugaan bahwa kami tidak bersungguh-sungguh hanya sekadar basa-basi saat melintas dalam perjalanan karena merasa kepanasan, juga karena kehujanan lalu kami singgah berteduh di bawah rumah kalian.)

Ungkapan di atas merupakan penjelasan dari juru bicara pihak laki-laki bahwa mereka (pihak keluarga laki-laki) bersungguh-sungguh untuk meminang anak perempuan keluarga yang didatangi sekaligus membuktikan bahwa kedatangan mereka beberapa hari yang lalu bukan untuk bermain-main. Kata-kata yang dipilih oleh juru bicara pihak laki-laki dalam menyampaikan maksud pembicaraan selalu menyesuaikan dengan kondisi masyarakat Tolaki. Misalnya ungkapan "umete'ete'ikomiu la'usamiu" (mencoba menaiki tangga kalian). Pemilihan ungkapan ini oleh tolea didasari oleh konteks kebudayaan masyarakata Tolaki dimana rumah masyarakat Tolaki zaman dahulu berbentuk rumah panggung walaupun saat ini rumah panggung sudah jarang ditemukan. Hal ini diperjelas lagi dengan ungkapan "mesoo'ako i lolu laika miu” yang berimplikasi berteduh di bawah rumah.

Selanjutnya juru bicara pihak laki-laki juga memberikan jawaban dengan ungkapan : 
“arimiu leu ihawi, inipua notule'i ilaakaa leu simungguru komami, lumolamakomami ki'oki no'une sawatu'umiu nggoleu modulu owine, mosimbi wuta mohair. Mano ona nggitu'o noilaando buakee, lumosongge owoseno unemami, wanggano penaomami tailaanggisumaasala'i, rongahumalahala'i no ate putemiuki, penao moroamiu. Tetongo'ito bitemui, tewalu'ito ineamiu ite mbo'asamiu, inea mbesarapumiu maa iamokaa nosuru laamami mogame-game komiu ronga mosanggasanggarakomiu iee no opu'anoki wulunggiremiu tumusa'ikomami. Maa iamokaa saru ipe'oli-oli lakokomiuto'ona mosunggeti toono laa tinumbaino o'ane, kinaputino balandete tuaranoto sangia, urano lahuene kilaa taa tinooriako akito tinooriako. Leukomiuto'ona mobutu tu'o mbineraha-raha hopulo-hopulo okae ari isakua ano onggo pinole osaku kinotu otawa pinuri o api nggo'inggomiu wuluako"

Terjemahan :

Sekembali dari kunjungannya yang lalu mungkin hanya sekadar berbasa-basi bukan atas kesungguhan hati dalam keinginan untuk menyambung tali silaturahmi tetapi kini, sudah diwujudnyatakan betapa besar hati, kesungguhan cita-citanya dan bukan sekadar berbasabasi tetapi memang dengan hati yang suci dan jiwa yang murni. Kini telah dipersembahkan bungkusan sirih pinang sebagai tanda pertunangan tentu saja bukan umpan tawaran dari kami, tetapi atas kesungguhan anda sendiri ingin mengangkat derajat keluarga kami. Tetapi jangan sampai menyesal anda telah menjumpai keluarga yang tak punya. Sungguh kami bersyukur dalam keadaan kami dipandang terselubung, kelak akan turut diperhitungkan. Keluarga yang anda tuju tidak memiliki apa-apa kecuali bermodal jari tangan. Segala sesuatu kebutuhan yang bertalian dengan itu menjadi beban dan tanggung jawab anda).

Ungkapan di atas merupakan jawaban dari juru bicara pihak perempuan yang mengandung makna menerima pinangan dari pihak keluarga laki-laki. Di sini ia terkesan merendahkan derajat keluarga perempuan seperti pada ungkapan:

"Maa iamokaa saru ipe'oli-oli lakokomiuto'ona mosunggeti toono laa tinumbaino o'ane, kinaputino balandete tuaranoto sangia, urano lahuene kilaa taa tinooriako akito tinooriako. Leukomiuto'ona mobutu tu'o mbineraha-raha hopulo-hopulo okae ari isakua ano onggo pinole osaku kinotu otawa pinuri o api nggo'inggomiu wuluako"

\section{Terjemahan :}

Tetapi jangan sampai menyesal anda telah menjumpai keluarga yang tak punya. Sungguh kami bersyukur dalam keadaan kami dipandang terselubung, kelak akan turut diperhitungkan. Keluarga yang anda tuju tidak memiliki apa-apa kecuali bermodal jari tangan).

Setelah pinangan pihak laki-laki diterima, selanjutnya pihak laki-laki yang diketuai/diwakili oleh Tolea (juru bicara pihak laki-laki) mempertanyakan pokok adat, yang harus dipenuhi oleh pihak laki-laki. Pokok adat adalah seserahan yang harus dipersiapkan oleh pihak laki-laki sebagai syarat memperistri anak perempuan dari keluarga tuan rumah. Selanjutnya adalah mempertanyakan kepada pihak keluarga perempuan melalui Pabitara sebagai juru bicara pihak perempuan perihal waktu dan mahar perkawinan.

Dalam proses ini terjadi dialog yang panjang mengenai mahar yang harus dipenuhi oleh keluarga laki-laki, yang diawali dengan pertanyaan juru bicara pihak laki-laki kepada juru bicara pihak perempuan mengenai segala sesuatu yang berhubungan dengan penyelenggaraan pesta yang dijawab oleh juru bicara pihak perempuan dengan ucapan : "maa keno tekonggo laa wohano, laa tai nahuno, laa doino. Dadi wohano maa $i$ poawokeitotokaa te pato etu litere, epo sapi no ano owoseki, iepo odoi ipoawoketotokaa te onomambulo ojuta"

\section{Terjemahan :}

Jadi jika pesta diselenggarakan berarti ada berasnya, ada lauk-pauknya, dan ada uangnya. Jadi berasnya empat ratus liter, sapi yang besar, dan uang bawa saja enam puluh juta). 
Ungkapan ini memberikan kesan bahwa permintaan dari pihak keluarga perempuan tidak begitu membebani pihak keluarga laki-laki. Hal ini dapat dilihat dari penggunaan/pemilihan kata tokaa (saja) seperti pada kalimat wohano ipoawokeitotokaa te te pato etu litere, odoi ipoawokeitotokaa te onomambulo ojuta. (berasnya bawa saja empat ratus liter, uang bawa saja enam puluh juta). Dengan memilih kata tokaa (saja), permintaan yang sebenarnya cukup tinggi, seolah-olah menjadi lebih ringan atau sedikit.

Menangapi hal ini, juru bicara pihak laki-laki merespon dengan ucapan terima kasih dan kemudian kembali mengingatkan kepada pihak keluarga perempuan bahwa rombongan keluarga laki-laki berasal dari negeri yang jauh yaitu di negeri Raha.

"Tarimakasi owose lako ihanu miu pabitara ana motuhakonggu ikeni lipu i Wonggeduku inggomiu ino mburaha mbulaika. Arikomiu to kumuu kuu ikomami, kumoa-koa ikomami metarambuu ari ine puи no osara, dunggu ine samba-samban. Aanamotuo meohai kipaha manasa ito ronga mendetee ito. Inono ana motu'o ari ikiromune i Raha mondotiho anamotu'o dadio toono meohai mano arikomiu to sumaru ikomami maa ine puu no osara inggomiu akiikaa mongoni sarai kipepepohawa, pepemeriako.

Terjemahan :

Terima kasih banyak kami ucapkan kepada juru bicara pihak perempuan dan seluruh orang tua kami di sini di Wonggeduku yang bertindak sebagai sebagai tuan rumah. Kalian telah memberikan penjelasan yang sangat jelas, mulai dari pokok adat sampai pada cabangcabangnya. Dan kamipun sudah memahami dengan jelas. Mereka ini berasal dari Raha. Orang tua kami dan seluruh kerabat, kalian memang telah memberikan penjelasan dengan jelas. Jadi untuk pokok adat, kami meminta untuk diingat dan dikasihani.

Tujuan juru bicara pihak laki-laki menyampaikan ini adalah untuk memberikan pandangan kepada pihak keluarga perempuan bahwa rombongan yang berasal dari jauh tentu akan menggunakan biaya yang besar. Untuk itu pihak keluarga laki-laki meminta untuk dikasihani, maksudnya pihak laki-laki meminta beras dan uang permintaan dari pihak perempuan untuk dikurangi.

Selanjutnya Pabitara menanggapi dengan ucapan :

"Dadi maa hendeino maa owoha nggo tekeha ka ate aaso etu laa ipo tolu etu, iepo hae doino maa nggo monggeha komiu ka ate aso juta. Dadi maa nggo limambulo osio ojuta. Iepo hae osapi maa nggo iyee tokaa."

Terjemahan :

Jadi kalau begitu, beras dikurangi seratur liter berarti masih tiga ratus liter, dan uangnya kami akan kurangi satu juta. Jadi masih lima puluh sembilan juta. Adapun sapinya tidak ada perubahan).

Kemudian dijawab oleh juru bicara pihak laki-laki dengan menggunakan bahasa kiasan:

"Ingoni ino ari komiuto sumaru ikehero mobeano ronga molitono nggo pino'aharo, nggo nirongo-rongo ro nggo mbule i Raha i kua ine ana motu'o. Keno hende bara no hanu ni rongo nggo pino aha, po'opo rohori moko rongo'i, moko po'aha'i.

Terjemahan :

Beberapa saat yang lalu, kalian telah menyampaikan berat dan ringannya beban yang akan mereka pikul, yang akan mereka jinjing untuk pulang ke Raha kepada orang tua mereka. Jika seandainya ini barang pikulan atau jinjingan, mereka belum mampu untuk memikul dan menjinjingnya.

Juru bicara pihak laki-laki mengkiaskan mahar yang harus dipenuhi oleh laki-laki dengan kata barang pikulan. Ia mengatakan bahwa pihak keluarga laki-laki belum bisa memikul beban atau barang pikulan yang diminta oleh pihak keluarga perempuan yang berimplikasi keluarga laki-laki belum mampu memenuhi permintaaan pihak keluarga perempuan. Untuk itu kelurga laki-laki melalui juru bicaranya kembali meminta pengurangan. 
Selanjutnya juru bicara pihak laki-laki dengan kemampuannya bernegosiasi kembali meminta kepada pihak keluarga perempuan melalui juru biicara pihak perempuan dengan menggunakan bahasa yang halus, seperti pada ungkapan :

"Ni'ino sinosara ro laa pepepeohawa pepe meriako ino, rosaru ikona ino baara de'ela laa mongoni lako ihanu miu ana motuo i Wonggeduku. No mondae ni'ino ari aro aro ikaa baara deela la lako popo'ahai woharo i kapala ano bosoro kambili ro, to oto kero dunggu keito. Lialia keepeo bara osapi maa amoto teeni nggo peula i kapala, no mondae ni'ino ari i polabuha laa aro, oki hula keno hori dunggu ipolabuha keto mesambuuleleo'ako itahi. Ieto aro laa mongoni ni'ino pepepeohawa pepemeriako lako ihanu miu ai wowo monggo'aso ikeheroto bara, ano inggomiu tokaa bara ikeni anamotu'o moko laa iketo o woha, mokolaaikeeto osapi.

Terjemahan :

Ini adalah adat dari mereka yang meminta belas kasihan. Mereka mewakilkan kepada saya untuk memohon belas kasihan kepada orang tua di Wonggeduku. Berhubung mereka berasal dari jauh, jangan sampai ketika mereka memikul beras mereka di atas kapal, karung mereka bocor sehingga mereka tidak bisa sampai ke sini. Apalagi sapi, jangankan naik di kapal mungkin belum sempat sampai di pelabuhan sapinya sudah jatuh di laut. Itulah sebabnya mereka meminta belas kasihan dari kalian kiranya semua bisa diikat/simpul satu kali, uang dan sapinya mungkin keluarga perempuanlah yang menyiapkannya.

Permintaan halus nampak pada ungkapan di atas. Juru bicara pihak laki-laki menggunakan kalimat "wowo monggo'aso ikeheroto" (diikat/disimpul satu kali). Kata "wowo" (ikat/simpul) dipilih oleh juru bicara pihak laki-laki karena kebiasan masyarakat Tolaki mencari dan mengumpulkan kayu bakar kemudian diikat/simpul untuk kemudian dipikul dibawa pulang kerumah. Inilah yang mendasari juru bicara pihak laki-laki memilih kata "wowo" dalam menyampaikan maksud kepada juru bicara pihak perempuan yang tentunya sudah dipahami oleh seluruh hadirin yang ada pada saat itu. Makna dari "wowo monggo'aso ikeheroto" (diikat/disimpul satu kali) adalah permintaan pihak keluarga laki-laki agar permintaan pihak keluarga perempuan (beras dan sapi) disatukan saja dalam bentuk uang.

\section{Implikatur pada Tahap Keempat : Mowindahako (Penyelesaian Adat)}

Tahapan terakhir dalam proses upacara pernikahan masyarakat Tolaki adalah mowindahako. Mowindahako adalah penyerahan pokok adat atau seserahan adat lainnya, yang dirangkaikan dengan pernikahan/perkawinan. Untuk itulah pesta pernikahan/perkawinan dipersiapkan dengan sempurna baik oleh laki-laki yang akan menghadiri pesta tersebut, maupun pihak kelurga perempuan selaku tuan rumah. Dalam tahapan ini pihak keluarga laki-laki beserta rombongan yang deketuai/diwakili oleh Tolea (juru bicara pihak laki-laki) menuju ke rumah pihak keluarga perempuan di mana pesta pernikahan/perkawinan akan berlangsung. Tujuannya adalah untuk menyerahkan segala sesuatu mengenai kelengkapan adat sekaligus melaksanakan proses pernikahan/perkawinan.

Seperti tahap-tahap sebelumnya juru bicara dari pihak keluarga laki-laki mengawali pembicaraan dengan ucapan penghormatan kepada tokoh-tokoh adat, pemerintah dan seluruh hadirin yang hadir pada saat itu, yang selanjutnya dilanjutkan dengan penyerahan segala kelengkapan adat mowindahako kepada pihak keluarga perempuan sebagai persyaratan untuk melaksanakan pernikahan.

Implikatur percakapan mombesara yang terkandung dalam komunikasi/dialog pada proses ini lebih mudah dipahami karena lebih banyak menggunakan bahasa yang langsung. Hal ini karena dalam proses ini hanya merampungkan apa yang telah dibicarakan dan disepakati pada tahap sebelumnya. Hanya ada beberapa tuturan yang mengandung ungkapan, diksi dan gaya bahasa seperti pada ungkapan : 
“Inggomiu pabitara, nokapoto osara, no heoto peowai nggo tumotoki'ito, sumulahi'i peowai. Kutotokindonga'i, kupole mbonimbi'i itaangge tano onggopo ene-ene, irurunggee tano onggopo ina-ina'u. Aso - ruo - tolu - omba. Kulaando humei'i osara, mosaru peowai sara perapu'a, peowai ine more aki pera mbaako. Nopuumbuumamiki, nosoosoromamiki mobitara osara, mosaru peowai. Puu sinurungako, puusinehengako. Keno posulemamito osara, poruhu'amami onggo-nggo nimokula'akomami, nggohinondawakomami. Nggonimotipu'akomami, nggonimopupu'akomami .Ieto akulaa tumotaha'ikomami wotolumami. Motoha'ipo olawu mano motoha'ipo wotolumami. Morini'ipo iwoi mano morini'ipo wotolumami. Ki'oki keki mokula'ako, hondowa'ako. Mopupu'ako, motiwu'ako Ruru wuku'ako, tondundoola'ako. Pekaru'ako, pe'ananuko,ako. Pegege'ako, pemata waako. Beruru'ako, hongo-hongo mowatu'ako Pewulu'uso'ako, lumba-lumba olutu'ako Akiki morini, akiki monapa. Morini mbuumbundi, monapa mbuundawaro Hende laa metuutudu i mata bondu, mehau-hau i matanggonawe. Aki kumunggu ana, aki humalu rapu. Metotoro oloho, mesuke ndaliawa. U'uuno hina, nggau-nggau oleo Nggo lalaie'ikaa nduunduuno tukomami, palimbali uwamami. Mobitara osara, mosaru peowai. Sara ine tina, peowai ine more. Aso - ruo - tolu - omba.

\section{Terjemahan :}

Yang kami hormati juru bicara pihak perempuan. Berhubung adat telah sampai, niwindahako sudah terpenuhi. Acara adat kami sudah sampai di sini. Segala kekurangan dan kelebihannya. Kami mohon untuk dimaafkan. Satu - dua - tiga - empat. Aku mengungkit adat. Berhubung kami pernah membicarakan masalah adat. Yakni adat perkawinan.Kami tak akan terkena bala, Kami memang pewaris yang kharismatik. Mengurus dan membicarakan masalah adat. Sudah dikukuhkan juga dinobatkan. Jika mungkin kami memutarbalikan kebenaran, yang dapat menghangatkan tubuh kami. Serta memendekan usia kami itulah sebabnya aku memantang tubuh kami. Sehingga akan tegar dan kuat di atas kuatnya besi. Tubuh kami akan terasa dingin dan sejuk di atas sejuk dan dinginnya air. Suhu badan kami tidak akan meninggi. Jauh dari segala macam penyakit. Kami akan selalu merasa sejuk dan nyaman laksana sejuk di rumpun pisang, nyaman di rumpun sagu. Sampai pada usia yang cukup lanjut. Tetap berada di tengah anak cucu laksana pohon olo-oloho. Masa berganti masa Kami akan tetap tegar Walau tongkat berganti tongkat, dan uban menghiasi kepala Kami akan terus mengurus dan membicarakan masalah adat istiadat perkawinan. Satu - dua - tiga - empat

\section{Simpulan}

Berdasarkan hasil Penelitian ini menunjukan bahwa percakapan Mombesara adat perkawinan etnis Tolaki didukung oleh unsur-unsur implikatur. Salah satu tahapan dalam proses upacara pernikahan masyarakat Tolaki adalah mowindahako. Mowindahako adalah penyerahan pokok adat atau seserahan adat lainnya, yang dirangkaikan dengan pernikahan/perkawinan. Untuk itulah pesta pernikahan/perkawinan dipersiapkan dengan sempurna baik oleh laki-laki yang akan menghadiri pesta tersebut, maupun pihak kelurga perempuan selaku tuan rumah. Dan dari ke empat tahap tersebut terdapat percakapan yang maknanya tidak disampaikan secara langsung yaitu pada tahap Morakerakepi (meninjau calon istri), tahap Monduutudu (pelamaran penjajakan), tahap Mondonggo Niwule/Moawo Niwule (peminangan resmi), dan tahap Mowindahako (upacara adat perkawinan/penyelesaian).

\section{Ucapan Terima Kasih}




\section{Daftra Pustaka}

Aminuddin. 2015. Semantik Pengantar Studi tentang Makna. Bandung: Sinar Baru Algensindo.

Alan, A. (2019). Kajian Semantik Tuturan Mombesara Pada Upacara Adat Perkawinan Suku Tolaki. Aksara Public, 3(2), 114-127.

Arliwan, D. (2019). Mombesara Discourse In Wedding Ceremonies Of Tolakinese Society. Jurnal Akrab Juara, 4(1), 220-233.

Chaer. Abdul.2012. Linguistik Umum. Yogyakarta: Rineka Cipta.

Djajasudarma, Fatimah.2012. Percakapan dan Pragmatik. Bandung:Rafika Aditama.

Franciska, B. (2014). Bentuk, Fungsi, dan Makna Interior Rumah Adat Suku Tolaki dan Suku Wolio di Sulawesi Tenggara. Intra, 2(2), 257-270.

Hadi, S. (2017). Hukum Positif dan The Living Law (Eksistensi dan Keberlakuannya dalam Masyarakat). DiH: Jurnal Ilmu Hukum.

Husba, Z. M. (2015). Tuturan Mekuku: Sistem Penanda Etnis dalam Interaksi Sosial Suku Tolaki di Sulawesi Tenggara. Patanjala, 7(2), 327-344.

Koodoh, E. E. (2018). Moambongi Ronga Monggolupe: Conflict and Integration in the Tolaki People of Konawe. Journal of Islam and Science, 3(1), 33-60.

Laela, F. N. (2014). Konseling Perkawinan sebagai salah satu upaya membentuk keluarga bahagia. Jurnal Bimbingan dan Konseling Islam, 2(1), 112-122.

Munir, M., Suardika, I. K., \& Moita, S. (2019). Makna simbolik Kalosara dalam kehidupan Suku Tolaki di Kabupaten Konawe. Jurnal Penelitian Budaya, 4(1).

Musdalifa, A. (2016). Nilai-Nilai Budaya dalam Tiga Cerita Rakyat Tolaki (Pendekatan Sosiologi Sastra). Jurnal Humanika, 3(16).

Rohmadi, Muhammad. 2010. Analisis Percakapan Pragmatik. Surakarta: Yuma Pustaka.

Subroto, Edi. 2011. Pengantar Studi Semantik dan Pragmatik. Surakarta: Cakrawala Media

Sugiyono. 2016. Metode Penelitian Pendidikan: Pendekatan Kuantitatif,Kualitatif, dan R\&D. Bandung: Alfabeta.

Wulandari, K. R., \& Suyuti, N. (2018). Morumbandole: Perubahan Tradisi Pernikahan pada Suku Tolaki di Kecamatan Abuki, di Kabupaten Konawe. Jurnal penelitian budaya, $3(1)$.

Zainal, A. Z. (2005). Konflik dan Kompromitas Adat dan Agama: Kasus perkawinan Suku Tolaki di Sulawesi Tenggara. Universitas Gajah Mada, Yogyakarta. 